\section{Lobbying of NSF denied}

SIR - In "US engineering research: Six special centres founded", (Nature 11 April, p.488; 1985), Tim Beardsley reports on several grants made by the National Science Foundation (NSF) to establish major engineering research centres. At the end of the article, Beardsley implies that political influence was involved in the selection of one of the awardee institutions. This letter's erroneous implication could cause great potential harm.

Beardsley states: "At least one US senator had lobbied NSF to locate an engineering research centre in his state, apparently successfully. But Bloch [Erich Bloch, director of NSF] insists that siting decisions had been made exclusively on the basis of peer review of the 142 proposals from 106 institutions."

The only communication about this matter that NSF received from the senator concerned was a form letter asking for information about the proposal on behalf of a constituent. That would hardly seem to constitute "lobbying" even by the most rigid of definitions.

Beardsley apparently reached his conclusion after reading a press release issued by the senator's office that seemed to imply a greater involvement. Other writers attending the press conference about the awards correctly identified this as a case of a political figure being overzealously associated with an event beneficial to his constituency. Beardsley's statement beginning, "But Bloch insists..." does not help matters greatly.

NSF goes to great lengths to ensure that decisions on all proposals are made on the basis of scientific merit and that the scientific and engineering communities are aware of and confident in that fact. In the case of the engineering research centre proposals, the review involved a four-stage process in which a number of competent persons participated, including highly respected engineers from academia and industry. Let me state clearly that politics was not and is not part of the process. The implication in the Beardsley article to the contrary is most unfortunate.

Office of Legislative

RAYMOND E. BYE JR and Public Affairs,

National Science Foundation,

Washington, DC 20550, USA

Tim Beardsley writes: While there is no evidence that NSF's reviewing was in fluenced by political pressure, the form letter referred to, from Senator Alfonse D'Amato of New York, was sent to NSF in response to a request for support from $\mathrm{Mr}$ Gregory Fusco, vice-president of government relations at Columbia University. The senator's involvement was readily confirmed by his office at the time the story was written. Senator D'Amato asked NSF to keep him informed of the progress of Columbia University's application and asked that Mr Fusco's request "be given every consideration". Some might disagree with Mr Bye's assertion that this does not constitute lobbying (Oxford English Dictionary: "to seek to influence"). Only the over-sensitive, however, would object to the word "insists" in connection with Bloch's denial that political factors influenced the selection process; insisting that one is innocent carries no implication that the opposite is true.

\section{Embryo research}

SIR - In their attempt to establish a status for the in vitro fertilization embryo, which denies the scientific understanding of the human embryo and the medical code of ethics in regard to it, Drs Evans and McLaren make some remarkable points!

They castigate Professor Lejeune because he ". . omits to say that research on the detection and prevention of these genetic defects... in some instances can only be done at this early (embryonic) stage" while omitting to point out themselves that most developmental genetic research work can be and is being done on ethically suitable animal and insect models. Indeed, Nature is organizing an international conference ("Genes and Systems in Development", San Francisco 7-9 October $1985)$ "to address what is perhaps the central unanswered question of biology today: How is the process of development directed by genes?" Most of the papers are based on animal models.

When the normal developmental processes of pattern formation are understood, then the abnormal processes can be solved - for how can one hope to understand the pathological without a proper understanding of the normal? In regard to the use of insect embryo models for understanding genetic development, David Ish Horowicz has suggested a relatively short time span: "It is conceivable that within 5 years it will all be over. We will have solved the universal biological problem of pattern formation" 3 . Allowing a further five years to solve the question of abnormal pattern formation (genetic defects), the answers should be available before the turn of the century. In the meantime, we can console ourselves in the knowledge that infants with genetic defects comprise less than 1 per cent of live births and 993 out of every 1,000 embryos, which implant with genetic defects, will not result in a live birth ${ }^{4}$.

89 Davies Road,

\section{Claremont, Perth,}

\section{Western Australia 6010}

1. Evans, H.J. \& McLaren, A. Nature 314, 127+128 (1985). 2. Moore K.L. The Developing Human, 8 (Saunders, Philadelphia, 1973).

3. Vines G. New Sct. No. 1483, 30 (1985).

4. Schlesselman J.J. Am. J. Obster. Grnecol. 135, 135 (1979). @) 1985 Nature Publishing Group

\section{Women students}

SiR - In his article, "Women in science and engineering", (Nature 2 May, p.84), Richard Pearson suggests that the cause of the surprisingly low representation in the "less traditionally heavy engineering" field of electrical engineering and electronics may be that "the competition for places is much harder in these subjects".

Surely this implies that women engineers are simply not as able as men in the field of electrical engineerng and electronics, and therefore cannot compete for these jobs?

I find this an extraordinary suggestion from a member of the Institute of Manpower Studies, but comparable to the engineering careers consultant at my old university who advised all female engineers to become accountants.

ElizabeTh Fisher

42 Salisbury Avenue,

Cheam, Surrey SMI 2DJ, UK

SIR - In Richard Pearson's article on sexual discrimination (Nature 2 May, p.84) there is an important difference between what is purported to be the percentage of medical students in the United Kingdom who are women, and what the government believes the figure to be. Pearson's Table 1 gives 49 per cent as the percentage of firstyear women medical students in 1982 (a figure he attributes to the Universities Central Council on Admissions). The Department of Health and Social Security publication On the state of the public health for the year 1983 (HMSO) gives the percentage number of women entrants in UK medical schools in 1982-83 as 44 per cent, and for the previous year 43 per cent. Whom do we believe? Medicine being what it is, I imagine the DHSS figure is nearer the mark.

JOE COLliER

St George's Hospital Medical School,

Department of Pharmacology,

Jenner Wing, Cranmer Terrace,

London SWI7 ORE, UK

\section{Liberation all round}

SIR - We were appalled to read the report from R.A. Tatouille (Nature 28 March, p.323) on the formation of the Vegetable Liberation Front. This is elementism of the worst kind. We have formed the Association for the Liberation of Long Oppressed Ingots to counter this oppression, and to lobby support for non-carbon based objects.

Remember the rallying cry of ALLOI "Metals of the World unite - you have nothing to lose but your purity".

GUY A. BROWN

DSIR Ilam Research Centre,

W.H. SWALLOW

27 Creyke Road,

PO Box 29-181,

Christchurch,

New Zealand 